Article

\title{
Adult Vocational Qualifications Reduce the Social Gradient in Education
}

\author{
Bernt Bratsberg ${ }^{1}$, Torgeir Nyen ${ }^{2, *}$ and Oddbjørn Raaum ${ }^{1}$ \\ ${ }^{1}$ Ragnar Frisch Centre for Economic Research, 0349 Oslo, Norway; E-Mails: bernt.bratsberg@frisch.uio.no (B.B.), \\ oddbjorn.raaum@frisch.uio.no (O.R.) \\ ${ }^{2}$ FAFO-Institute for Labor and Social Research, 0608 Oslo, Norway; E-Mail: torgeir.nyen@fafo.no \\ * Corresponding author
}

Submitted: 25 February 2019 | Accepted: 11 June 2019 | Published: 5 September 2019

\begin{abstract}
Many youth leave school early without an upper secondary education, impeding their chances in the labor market. Early school leavers come disproportionately from families with low parental education. In some countries, there are alternative routes to upper secondary qualifications as adults. Does adult attainment reduce initial social differences in educational attainment, or does it reinforce such differences? Norway is one of the countries where many attain upper secondary qualifications in adulthood. Using individual data from administrative registers, we follow five Norwegian birth cohorts (1973-1977) from age 20 to 40. We document that the association between parental education and upper secondary completion declines monotonically with age, ending at age 40 about $35 \%$ below that at age 20 . We also document that the alternative routes to adult qualifications recruit students of different family backgrounds. In particular, adults who acquire vocational qualifications via the experience-based route come from families with lower education than other groups. Our evidence suggests that institutions that offer opportunities for certifying qualifications acquired at work mitigate social gradients, fostering more equal opportunities within the education system.
\end{abstract}

\section{Keywords}

adult qualifications; family background; intergenerational education; vocational education and training

\section{Issue}

This article is part of the issue "Types of Education, Achievement and Labour Market Integration over the Life Course", edited by Irene Kriesi (Swiss Federal Institute for Vocational Education and Training, Switzerland) and Juerg Schweri (Swiss Federal Institute for Vocational Education and Training, Switzerland).

(C) 2019 by the authors; licensee Cogitatio (Lisbon, Portugal). This article is licensed under a Creative Commons Attribution 4.0 International License (CC BY).

\section{Introduction}

The links between social background and educational attainment are well documented (e.g., Hansen, 1997; Rumberger, 1987). Parental educational attainment is a particularly important factor (Haveman \& Wolfe, 1995). The persistence in educational outcomes across generations is high in many countries, with a parent-child correlation in years of schooling of about 0.4 (Hertz et al., 2007). While early school leaving is more frequent among adolescents growing up in low-education families, educational systems that offer opportunities for adults to acquire qualifications may mitigate such social differences. In many countries, including Norway, a considerable number of early school leavers acquire formal qualifications as adults (OECD, 2014, p. 54).

Our study contributes to the literature on social gradients in education by studying acquisition of qualifications during adulthood for those who left school early without completed upper secondary education. Do upper secondary qualifications acquired as adults influence how educational attainment differs by parental education? Drawing on longitudinal data from Norwegian administrative registers, we track the educational attainment of individuals through age 40 and document how the association between parental education and upper secondary completion changes with age. Evidence from Norway is informative because a large number of adults 
acquire upper secondary qualifications for the first time in their 20s and 30s and a high proportion of these achieve vocational qualifications. We examine four alternative routes to adult qualifications-experience-based vocational certification; adult apprenticeships; schoolbased vocational degrees; and academic tracks. Since the first two routes rely heavily on learning at work, they may recruit differently compared to school-based tracks. As traditional learning environments may present an obstacle to completion of upper secondary education for those growing up in low-education families (IIleris, 2004), our main hypothesis is that tracks based on learning at work will reduce attainment differences by parental education.

Although the persistence in educational outcomes across generations is strong, the correlation coefficient between years of schooling of parent and child varies across countries and over time (Breen, Luijkx, Müller, \& Pollak, 2009; Hertz et al., 2007). How strongly educational attainment relates to parental schooling will depend on institutional characteristics, both for the education system at large and for specific routes. There is substantial variation across educational systems (see, e.g., Blossfeld, Buchholz, Skopek, \& Triventi, 2016). Compared to more uniform systems, the effects of social background tend to be stronger when students sort into different tracks at an early age, especially for entry into higher education (see, e.g., Ammermueller, 2013; Müller \& Karle, 1993). Norway has a uniform system that would be expected to produce comparatively small inequalities in attainment. Early tracking is in Europe often associated with dual systems with a higher level of specificity of vocational skills in the vocational track. If both tracks give access to good jobs and stable employment, sorting by social background presents less of a challenge to norms of equality and inclusion than when labor market outcomes are very different-which has been an argument in defense of educational systems with early tracking, such as that in Germany (Shavit \& Müller, 2006). The lower entry rates to higher education among youth with low education backgrounds in such systems may still be regarded as problematic from a social inequality perspective (Powell \& Solga, 2011). Even selection into vocational education relates to family educational background. Participation in vocational education is skewed in favor of medium rather than low and high education families (Beicht \& Walden, 2015), while school leavers tend to have a low education family background.

Focusing more specifically on adult learning, the general literature on participation in adult learning (see, e.g., Blossfeld, Kilpi-Jakonen, Vilhena, \& Buchholz, 2014) documents large differences in participation according to background characteristics, indicating that adult learning does not necessarily reduce the correlation between attainment and parental years of schooling. The scarce prior evidence on participation in "second chance" education for adults who left school early, points to social gradients in attainment similar to the patterns observed for youth. Glorieux, Heyman, Jegers and Taelman (2011) study two different adult institutions/routes based on courses and home studying respectively. While they attract different groups, both institutions recruit participants from higher socio-economic backgrounds than students who never complete upper secondary education, leaving the authors to conclude that neither route is very effective in mitigating social inequality. In the US, evidence from the General Education Development (GED) test suggests that those who complete the GED test have a parental education background similar to those who complete high school in their youth, but lower than those who go on to college (Heckman, Humphries, \& Mader, 2010, p. 15).

Social recruitment patterns in adult education are likely to reflect the specific institutions available for obtaining adult qualifications. In the studies cited above, the institutions require that adults either return to a classroom setting or study at home/alone (to pass a test). Previous research on adult learning suggests that institutions requiring adults to return to the classroom or study at home maintain educational differences by family background. The reason is that adults with a low parental education background often have low motivation for reentering school-based learning and learn more easily if learning is integrated with work (see, e.g., Illeris, 2004, 2006; Knowles, 1978). This may be due to negative experiences with traditional school learning (Illeris, 2004). The Norwegian case provides an opportunity to study how adults sort into routes since the institutions offer alternatives that rely heavily on workplace training as well as traditional school-based programs.

Our evidence on the associations between parental schooling and offspring education should not be interpreted causally as effects of higher parental education. Typically, estimates of parental education effects reflect selection on other factors (whether genetic or environmental) that are positively correlated with attainment in both generations. Using alternative identification strategies, Holmlund, Lindahl and Plug (2011) conclude that intergenerational schooling associations are largely driven by such selection. The motivation for our study is to provide evidence on the role of adult educational institutions in reducing inequality rooted in family background differences. For this, it is of minor interest whether the impact of parental education reflects causal mechanisms or captures other correlated factors.

\section{Adult Completion of Upper Secondary Education}

The starting point for our analysis is that the fraction of a birth cohort with completed upper secondary education increases with age. This pattern reflects that some youth take more than the statutory number of years to complete their upper secondary schooling, and that some adults return to school or certify their workplace training. In Norway, the statutory graduation age is 19 or 20, depending on the academic or vocational track, but as 
Figure 1 shows, fully $14.0 \%$ of men and $10.2 \%$ of women complete upper secondary education between ages 20 and 25 (age at end of calendar year). Completion during adulthood is also common: among women, $7.6 \%$ acquire upper secondary qualifications between ages 25 and 40 , while the male adult completion rate increases by 6.5 percentage points.

In Figure 1 we also split the sample in two according to parental education, i.e., by whether or not at least one parent had completed upper secondary education. There are large visible differences in completion according to parental education, but an important point from Figure 1 is that this differential declines with age. While the completion differential for men is $21.5 \%$ at age 20 , it shrinks to $18.0 \%$ at 25 , and is further reduced to $14.5 \%$ at age 40 . For women, the differential declines from $21.7 \%$ at age 20 , via $18.0 \%$ at age 25 , to $13.1 \%$ at age 40 . The declining female differential largely reflects that many women with low parental education complete upper secondary between age 25 and 40 .

\section{Adult Vocational Education Institutions}

In this section, we briefly outline the Norwegian education system, with an emphasis on the vocational education and training (VET) system and the routes available for adults to acquire vocational qualifications.

Primary and lower secondary education is uniform and lasts ten years. At age 16, youth enter upper secondary education and select into 13 distinct programs of which eight are vocational. The eight vocational firstyear programs branch out to 52 second-year courses and apprenticeships in almost 200 trades. Students may switch from a vocational program to an academic program during the course of study. Apprenticeship is an integrated part of nearly all vocational upper secondary programs. Most vocational programs follow the $2+2$ model, with two years in school followed by two years of apprenticeship training. After completing the apprenticeship period, apprentices who pass the trade examination achieve a certificate in a particular trade. Two prominent typologies of the VET system distinguish between the liberal, state-based and the dual systems (Busemeyer \& Trampusch, 2012; Greinert, 2004). The Norwegian VET system has been characterized as a hybrid system, combining elements from the dual and the state-based systems (Nyen \& Tønder, 2014; Olsen, Høst, \& Michelsen, 2008). It is worth noting that the Norwegian education system is not based on early tracking of students into academic or vocational tracks, even though apprenticeships form a pivotal part of the VET system.

Norwegian youth have the statutory rights to upper secondary education, and although not compulsory, $98 \%$ of 16 -year-olds begin upper secondary education. In recent years, between 40 and $45 \%$ of 16 -year-olds have started in a vocational program (Nyen, Skålholt, \& Tønder, 2015). However, less than half end up with formal vocational qualifications after four years. This is because of dropout and delayed completion, but also because many students in certain programs exercise the option of switching to an academic program.

Educational attainment in Norway is relatively high with $83 \%$ of 25 to 54 -year-olds having completed education at ISCED levels 3-4 (EQF 3) or above in 2017 (Eurostat, 2018). However, the share of young adults (age 20 to 24) with completed upper secondary educa-

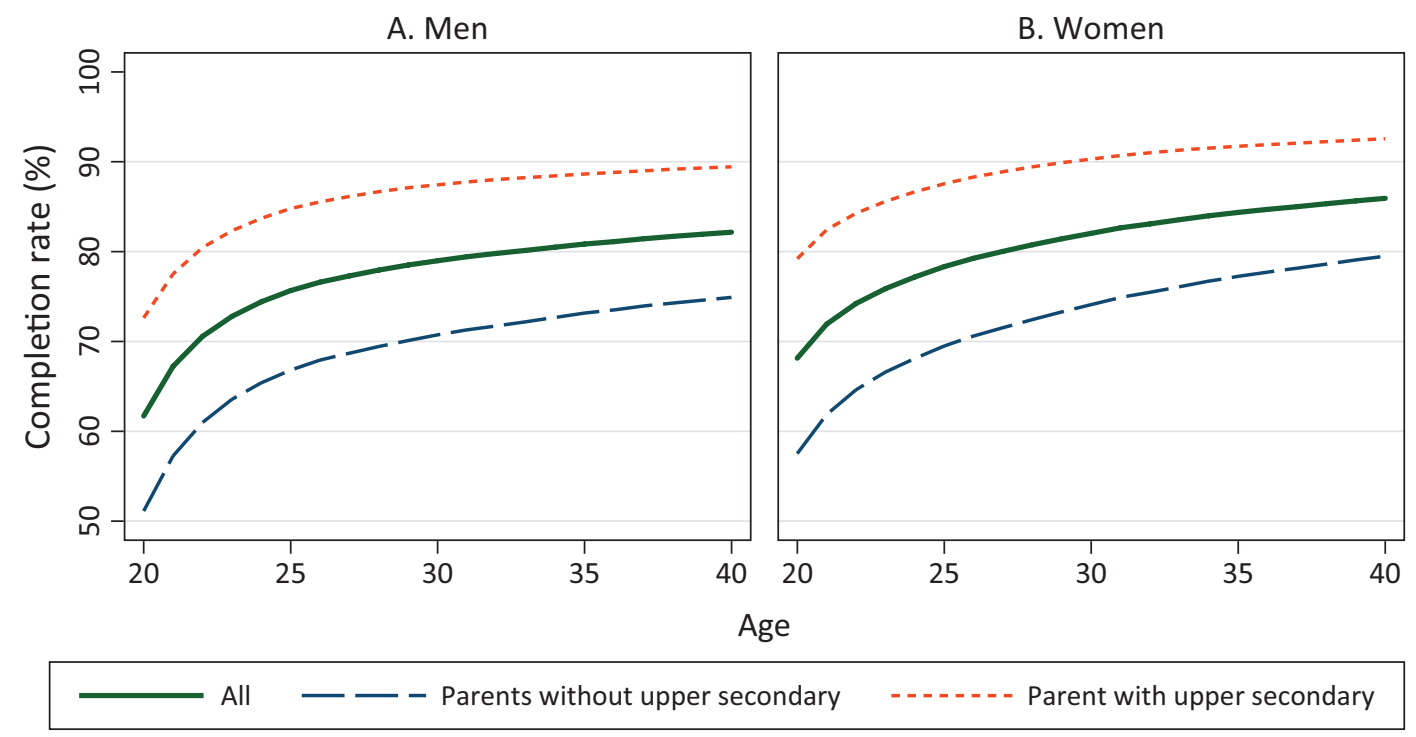

Figure 1. Completion of upper secondary education by age, gender, and parental education. Notes: Samples consist of 1973-1977 birth cohorts, with Norwegian-born parents and valid education data, and present in the country. Observation counts are 129,712 men and 124,109 women at age 20, declining to 125,207 men and 121,127 women at age 40. Data extracts are further described in Section 4. Completion rates for men are 61.7\% (age 20), 75.7\% (25), and $82.2 \%(40)$, and for women $68.1 \%$ (age 20), 78.3\% (25), and $85.9 \%$ (40). Parental education is observed at age 15 . The two parental education samples are of comparable size ( $51 \%$ had two parents without completed upper secondary education). 
tion (ISCED 3) is below the EU average. What makes overall attainment high is that many complete upper secondary education in their 20s or 30s (see Figure 1).

The high adult completion rate reflects that several routes are available for completing upper secondary education as adults. For vocational qualifications, the two main routes are adult apprenticeships and the experience-based route. Both lead to the same qualifications as those achieved by youth. Adult apprenticeships are similar to youth apprenticeships, but adults can have all their training at the workplace, except for that in general subjects. The experience-based route gives adults who can document a long and varied practice within a trade the chance to acquire the trade certificate, provided they pass a written exam and the ordinary trade examination. Most candidates take a theoretical preparatory course as well. The experience-based route accounts for as much as one third of all new trade certificates each year (Bratsberg, Nyen, \& Raaum, 2017). Contrasting the two routes, adult apprenticeship is a training scheme at the workplace available to both those previously employed and non-employed, while the experience-based route provides a chance for employed workers without formal vocational qualifications to certify the skills they have gained informally or through non-formal training.

Historically, a third vocational route has also been important, as many adult women, in particular, have completed school-based vocational educations in health care that have led to formal qualifications. These are threeyear school-based vocational courses leading to upper secondary qualifications. The most important of these programs, the auxiliary nurse program, closed in 2006 and was replaced by the apprenticeship-based health care worker program. For adults wanting to complete general, academic upper secondary education, there are adult education institutions for part-time studies that can be combined with work, forming a fourth route to adult upper secondary qualifications. This category also covers students accepted into higher education through validation of prior learning. In sum, in the empirical analyses that follow, we study four alternative routes to adult completion of upper secondary education: the experience-based route, adult apprenticeships, schoolbased vocational courses, and the academic track. Our hypothesis is that adult acquisition of upper secondary qualifications reduces the social gradient in education. Because re-entry into a classroom setting is known to represent a participation barrier for adults with a low parental education background (Illeris, 2006), we expect the routes based on workplace learning, and especially the experience-based route, to contribute more to the reduction in the social gradient than the vocational routes based on in-school learning and the academic track.

\section{Data and Empirical Approach}

Our study draws on merged individual records from two administrative registers, the central population register and the national education database. We first extracted all records of individuals born to two Norwegian-born parents between 1973 and 1977 and kept observations where the individual and both parents have valid registrations in the education database. The education database allows us to study completion through 2017, when the youngest of these cohorts was 40 years of age. Detailed data on routes to vocational qualifications are first available in 1998, limiting complete records for the five birth cohorts to the age span 25 to 40 . For this reason, and because we want to study adult routes to upper secondary completion, we focus on those who had not completed upper secondary at age 25. For simplicity of language, we use the term "dropouts" for this group, even though they have finished compulsory schooling. We track their attainment between 25 and 40, restricting samples to individuals present in Norway at age 40 . Nevertheless, for completeness Figures 1 and 3 cover the broader age span 20 to 40 because the displayed statistics do not require data on adult route to completion. The various restrictions reduce the overall sample by $5.9 \%$ and leave us with analysis samples of 125,207 men and 121,127 women. In these samples, $76.1 \%$ of men and $78.5 \%$ of women had completed upper secondary by age 25 (see Table 1, column 2). The data requirement that we observe parental education means that we exclude immigrants from the study population. Records from the national education database indicate that immigrants are overrepresented among those acquiring vocational upper secondary qualifications in adulthood, and we may therefore ignore an important link between adult education and reduced social inequality. We leave this topic for future research.

In Figure 2, we focus on dropouts without formal upper secondary qualifications at age 25 and show the fraction with completed upper secondary education at each age through 40 . In this subsample, one in four men and one in three women had acquired vocational qualifications or completed upper secondary through the academic track by age 40 . As the figure shows, men and women take somewhat different routes. For men, the experience-based route to the trade certificate is most common. For women, the academic track and schoolbased vocational education are more important (see also Table A1 in the Appendix which gives the top five fields of study by gender and route to adult completion).

In the study of adult completion and the alternative routes to adult upper secondary qualifications, we relate completion to family background measured by the sum of the parent's statutory years of schooling. We discuss this operationalization further in Section 6. Table 1 shows that the various groups differ importantly along this measure: while parental years of schooling is 24.5 and 24.4 on average among men and women who completed upper secondary by age 25 (column 2), parental schooling is considerably lower at 21.2 and 20.8 for men and women who completed via the adult experience-based route (column 3 ). Of the four adult routes, parental education is higher among those completing via the aca- 
Table 1. Descriptive statistics: parental education.

\begin{tabular}{|c|c|c|c|c|c|c|c|}
\hline & \multirow[b]{2}{*}{$\begin{array}{l}\text { All } \\
(1)\end{array}$} & \multirow[b]{2}{*}{$\begin{array}{l}\text { Completed } \\
\text { age } 25 \\
\text { (2) }\end{array}$} & \multicolumn{5}{|c|}{ By adult route to completion age 40} \\
\hline & & & $\begin{array}{c}\text { Experience } \\
\text { based } \\
\text { (3) }\end{array}$ & $\begin{array}{c}\text { Apprentice } \\
\text { (4) }\end{array}$ & $\begin{array}{l}\text { School-based } \\
\text { vocational } \\
\text { (5) }\end{array}$ & $\begin{array}{c}\text { Academic } \\
\text { track } \\
(6)\end{array}$ & $\begin{array}{l}\text { Not completed } \\
\text { age } 40 \\
\text { (7) }\end{array}$ \\
\hline \multicolumn{8}{|l|}{ A. Men } \\
\hline Mother educ & $\begin{array}{l}11.6 \\
(2.45)\end{array}$ & $\begin{array}{l}11.9 \\
(2.52)\end{array}$ & $\begin{array}{l}10.5 \\
(1.75)\end{array}$ & $\begin{array}{l}10.7 \\
(1.99)\end{array}$ & $\begin{array}{l}10.6 \\
(1.99)\end{array}$ & $\begin{array}{l}11.6 \\
(2.48)\end{array}$ & $\begin{array}{l}10.6 \\
(1.87)\end{array}$ \\
\hline Father educ & $\begin{array}{l}12.2 \\
(2.91)\end{array}$ & $\begin{array}{l}12.6 \\
(2.96)\end{array}$ & $\begin{array}{l}10.7 \\
(2.13)\end{array}$ & $\begin{array}{l}11.2 \\
(2.41)\end{array}$ & $\begin{array}{l}11.3 \\
(2.39)\end{array}$ & $\begin{array}{l}12.0 \\
(2.83)\end{array}$ & $\begin{array}{l}10.9 \\
(2.31)\end{array}$ \\
\hline Parental educ & $\begin{array}{l}23.8 \\
(4.67)\end{array}$ & $\begin{array}{l}24.5 \\
(4.76)\end{array}$ & $\begin{array}{l}21.2 \\
(3.09)\end{array}$ & $\begin{array}{l}22.0 \\
(3.58)\end{array}$ & $\begin{array}{l}21.9 \\
(3.69)\end{array}$ & $\begin{array}{l}23.6 \\
(4.54)\end{array}$ & $\begin{array}{l}21.5 \\
(3.48)\end{array}$ \\
\hline $\begin{array}{l}\text { Observations } \\
\text { Sample share }\end{array}$ & 125207 & $\begin{array}{r}95247 \\
0.761\end{array}$ & $\begin{array}{r}3327 \\
0.027\end{array}$ & $\begin{array}{r}1200 \\
0.010\end{array}$ & $\begin{array}{l}271 \\
0.002\end{array}$ & $\begin{array}{r}2843 \\
0.023\end{array}$ & $\begin{array}{r}22337 \\
0.178\end{array}$ \\
\hline \multicolumn{8}{|l|}{ B. Women } \\
\hline Mother educ & $\begin{array}{l}11.6 \\
(2.43)\end{array}$ & $\begin{array}{l}11.9 \\
(2.50)\end{array}$ & $\begin{array}{l}10.2 \\
(1.53)\end{array}$ & $\begin{array}{l}10.5 \\
(1.79)\end{array}$ & $\begin{array}{l}10.3 \\
(1.65)\end{array}$ & $\begin{array}{l}11.1 \\
(2.21)\end{array}$ & $\begin{array}{l}10.4 \\
(1.70)\end{array}$ \\
\hline Father educ & $\begin{array}{l}12.1 \\
(2.89)\end{array}$ & $\begin{array}{l}12.5 \\
(2.94)\end{array}$ & $\begin{array}{l}10.6 \\
(2.21)\end{array}$ & $\begin{array}{l}10.7 \\
(2.21)\end{array}$ & $\begin{array}{l}10.7 \\
(2.21)\end{array}$ & $\begin{array}{l}11.5 \\
(2.62)\end{array}$ & $\begin{array}{l}10.7 \\
(2.18)\end{array}$ \\
\hline Parental educ & $\begin{array}{l}23.7 \\
(4.63)\end{array}$ & $\begin{array}{l}24.4 \\
(4.71)\end{array}$ & $\begin{array}{l}20.8 \\
(2.87)\end{array}$ & $\begin{array}{l}21.2 \\
(3.28)\end{array}$ & $\begin{array}{l}21.0 \\
(2.99)\end{array}$ & $\begin{array}{l}22.6 \\
(4.05)\end{array}$ & $\begin{array}{l}21.1 \\
(3.19)\end{array}$ \\
\hline Observations & 121127 & 95134 & 1865 & 866 & 2038 & 4214 & 17037 \\
\hline Sample share & & 0.785 & 0.015 & 0.007 & 0.017 & 0.035 & 0.141 \\
\hline
\end{tabular}

Notes: Sample mean (standard deviation), by gender and route to completion of upper secondary education. Samples consist of individuals born in Norway between 1973 and 1977 to Norwegian-born parents with valid education data, and who were present in the country at age 40 . Parental education is the sum of mother and father's years of schooling, observed at age 15 of the offspring.

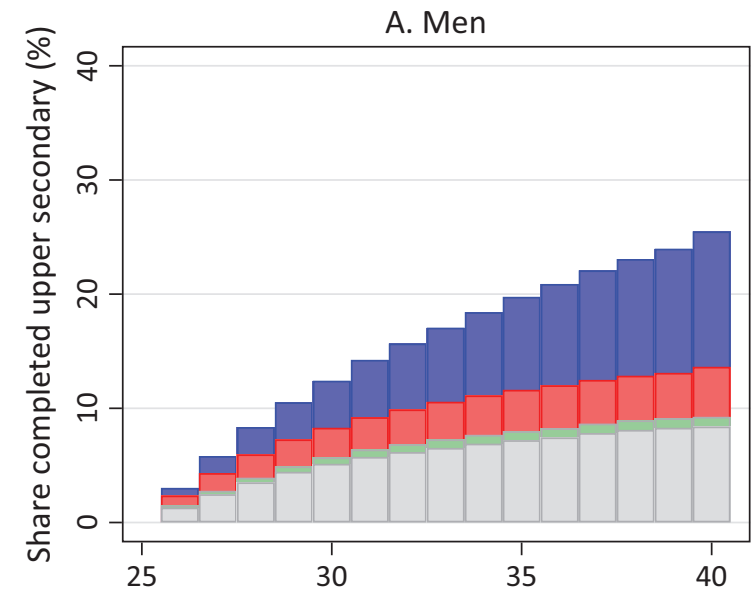

Age

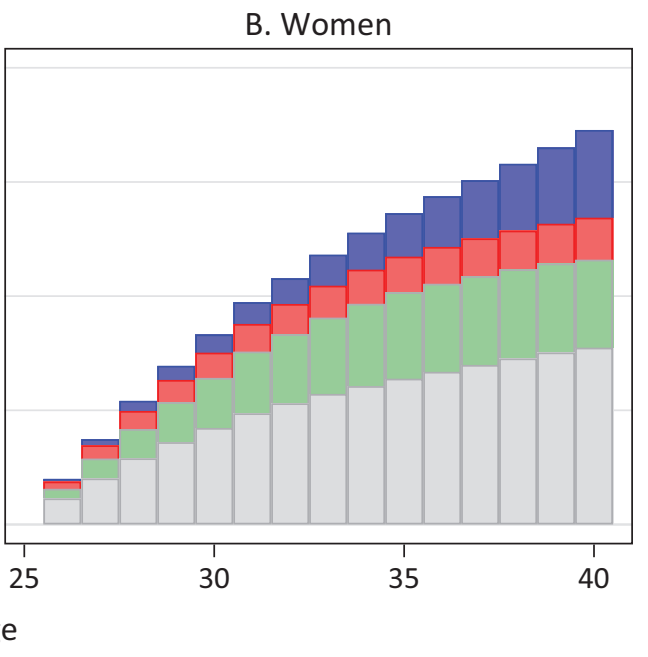

School-based vocational
Academic track

Figure 2. Routes to completion of upper secondary education if dropout at age 25 . Note: Observation counts are 29,960 men and 25,993 women.

demic track than the three vocational routes. Of particular note, parental education is lower for the experiencebased group than even for those who did not complete upper secondary education by age 40 (column 7), hinting that the route may play an important role in reducing differences in attainment by parental background.

Our empirical analyses build on estimation of the linear probability model. The baseline regression model re- lates completion at a certain age to the sum of parental schooling:

$$
C_{a i}=\alpha_{a}+\beta_{a}\left(S M_{i}+S F_{i}\right)+\varepsilon_{a i}
$$

where $C$ is an indicator variable for completed upper secondary education, SM and SF denote years of schooling of mother and father, and $a$ indexes age and $i$ the individual. When we examine the alternative adult routes to 
qualifications, we estimate four separate linear probability models:

$$
C_{j i}=\alpha_{j}+\beta_{j}\left(S M_{i}+S F_{i}\right)+\varepsilon_{j i}
$$

where $j$ indexes the four routes (experience-based; apprentice; school-based vocational; and academic track) and $C_{j}$ is an indicator for completion of upper secondary via route $j$ between ages 25 and 40 . In other words, in the next section we model upper secondary completion as a function of parental attainment, assuming that the marginal effect of parental schooling is constant and that schooling of the two parents is equally important for the offspring, and ignoring other family attributes that may affect completion of upper secondary schooling. In Section 6 , we relax each of these assumptions.

\section{Results}

To set the stage for the empirical analysis, we first display results from 42 separate estimations of equation (1) by age and gender. Figure 3 shows the estimates of the coefficient of parental education, along with their $95 \%$ confidence interval. At age 20 , the coefficient estimate is 0.029 for both men and women, showing that initial completion relates very strongly to family background. A coefficient of 0.029 means that an additional year of parental schooling is associated with a 2.9 percentage point higher completion rate. However, this advantage declines with age: at age 25 , it stands at 2.4 percentage points, and at age 40 , it is 1.9 points for men and 1.8 points for women (see also Table 2). In other words, the social gradient in education diminishes substantially with age.

As columns 1 and 2 in Table 2 show, over the age interval 25 to 40 , the gradient declines from 0.0235 to $0.0192(0.0043$ or $18 \%)$ for men, and from 0.0243 to $0.0175(0.0068$ or $28 \%)$ for women. The decline is highly statistically significant with $p$-values below 0.0005 for each gender (not shown in the table). The last four columns report the route-specific coefficients from estimations of equation (2) and reveal a consistent pattern across gender and routes, with completion in adulthood more likely the lower is the educational attainment of parents.

Although each of the four adult routes contributes to the reduction in the social gradient between age 25 and 40 (the sign of the parental education coefficient is negative across routes and gender), the roles of the various routes differ, and even so by gender. For men, vocational certification based on work experience is particularly important for two reasons. First, qualifications are frequently acquired via this route ( $2.7 \%$ of the male sample, or $11.1 \%$ of male dropouts). Second, the route relates strongly and negatively to parental education. Many men acquire academic qualifications, but the association of this route with parental education is much weaker than for the experience-based route (compare columns 3 and 6). Because, by construction, the increase in the completion rate between 25 and 40 is equal to the sum of the fractions completing via the four adult routes, the sum of the parental education coefficients in columns 3-6 equals the difference between coefficients in columns 2 and 1 . A convenient way of decomposing the change in the social gradient is therefore to divide each route-specific coefficient by the overall reduction in the gradient. According to this metric, for men the experience-based route accounts for fully $73.5 \%$ of the decline in the social gradient in education between ages 25 and 40 (see column 3, row labeled "contribution to decline").

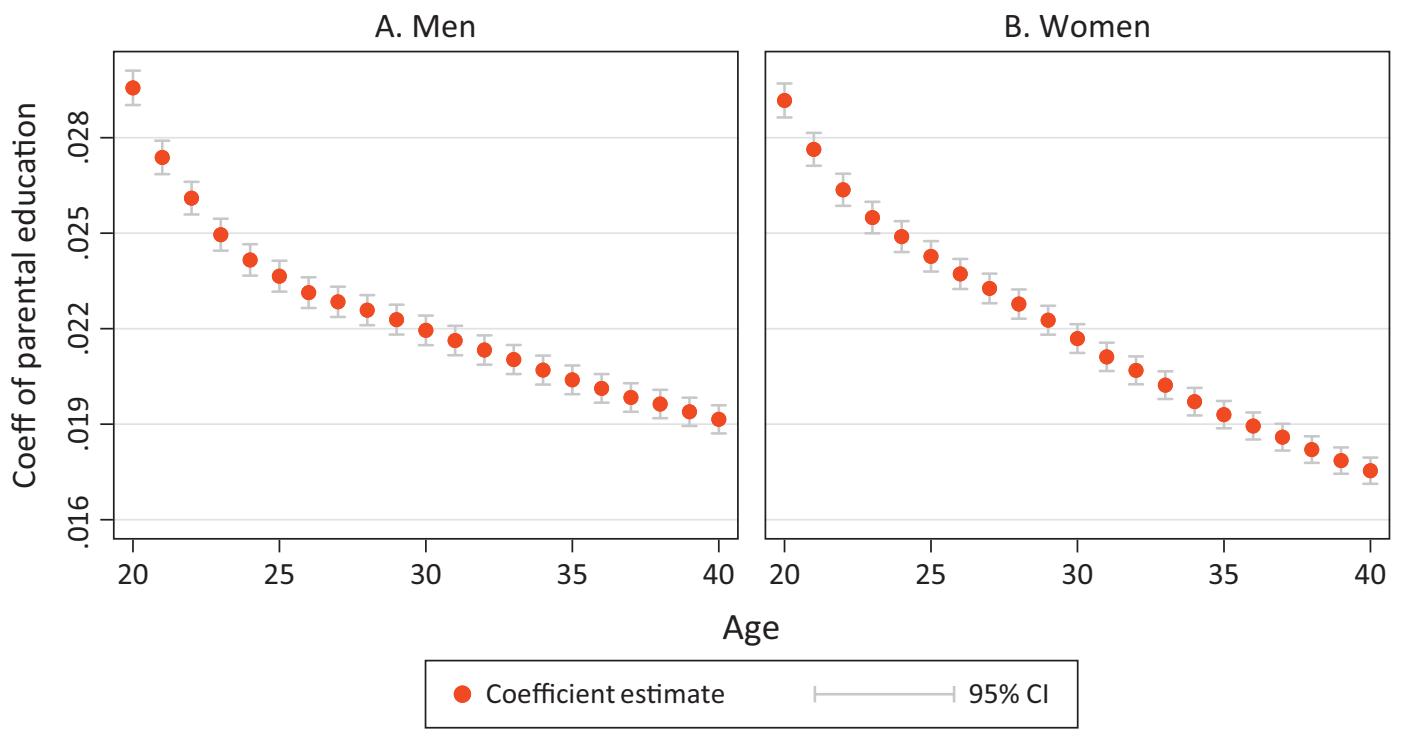

Figure 3. Completed upper secondary education: coefficient of parental education, by age and gender. Note: Scatter points are the coefficient estimates from 42 regressions run separately by age and gender of completion of upper secondary on parental education. 
Table 2. Completion of upper secondary education by ages 25 and 40 , by gender and by adult route. Effects of parental education.

\begin{tabular}{|c|c|c|c|c|c|c|}
\hline & \multirow[b]{2}{*}{$\begin{array}{l}\text { Completed } \\
\text { age } 25 \\
\text { (1) }\end{array}$} & \multirow[b]{2}{*}{$\begin{array}{l}\text { Completed } \\
\text { age } 40 \\
(2)\end{array}$} & \multicolumn{4}{|c|}{ Completion age 40 by adult route } \\
\hline & & & $\begin{array}{c}\text { Experience } \\
\text { based } \\
\text { (3) }\end{array}$ & $\begin{array}{c}\text { Apprentice } \\
\text { (4) }\end{array}$ & $\begin{array}{l}\text { School-based } \\
\text { vocational } \\
\text { (5) }\end{array}$ & $\begin{array}{l}\text { Academic } \\
\text { track } \\
(6)\end{array}$ \\
\hline \multicolumn{7}{|l|}{ A. Men } \\
\hline \multirow[t]{2}{*}{ Parental educ } & $0.0235^{* * *}$ & $0.0192 * * *$ & $-0.0032 * * *$ & $-0.0008 * * *$ & $-0.0002 * * *$ & $-0.0002 *$ \\
\hline & $(0.0003)$ & $(0.0002)$ & $(0.0001)$ & $(0.0001)$ & $(0.0000)$ & $(0.0001)$ \\
\hline Contribution to decline & & & 0.735 & 0.188 & 0.044 & 0.036 \\
\hline $\operatorname{Adj} R^{\wedge} 2$ & 0.0659 & 0.0545 & 0.0084 & 0.0015 & 0.0004 & 0.0000 \\
\hline Observations & 125207 & 125207 & 125207 & 125207 & 125207 & 125207 \\
\hline Mean dep var & 0.761 & 0.822 & 0.027 & 0.010 & 0.002 & 0.023 \\
\hline \multicolumn{7}{|l|}{ B. Women } \\
\hline \multirow[t]{2}{*}{ Parental educ } & $0.0243^{* * *}$ & $0.0175^{* * *}$ & $-0.0021 * * *$ & $-0.0008 * * *$ & $-0.0021 * * *$ & $-0.0017^{* * *}$ \\
\hline & $(0.0002)$ & $(0.0002)$ & $(0.0001)$ & $(0.0001)$ & $(0.0001)$ & $(0.0001)$ \\
\hline Contribution to decline & & & 0.310 & 0.124 & 0.314 & 0.257 \\
\hline $\operatorname{Adj} R^{\wedge} 2$ & 0.0753 & 0.0545 & 0.0062 & 0.0021 & 0.0059 & 0.0019 \\
\hline Observations & 121127 & 121127 & 121127 & 121127 & 121127 & 121127 \\
\hline Mean dep var & 0.785 & 0.859 & 0.015 & 0.007 & 0.017 & 0.035 \\
\hline
\end{tabular}

Notes: * $/ * * * * *$ statistically significant at $10 / 5 / 1 \%$ level. Standard errors are reported in parentheses. Row labeled "contribution to decline" shows the ratio of regression coefficient to the reduction in overall coefficient between ages 25 and 40 .

Women are more evenly distributed across the alternative routes, even if adult apprenticeships are less frequent than for men. The contributions to the decline in the gradient are also more similar across routes. More women than men complete via the academic track, and the association with parental education is stronger than for men.

Further insight into the social gradient of adult secondary completion can be gained by focusing on those who had not completed at age 25. While Table 2 examined the contributions of the four adult routes to the decline in the social gradient, in Table 3 we explicitly study dropouts at age 25 and address differences in adult recruitment patterns across routes. First, however, column 1 of Table 3 shows that the overall adult completion rate remains strongly and positively associated with parental education. Even among dropouts, having more educated parents increases the probability of completion between ages 25 and 40 . The average parental education effect is substantial-an additional year of parental education is associated with a 1.15 percentage point higher completion rate among males and 1.40 percentage point higher completion among females. The recruitment into experience-based qualifications is, however, very different from that of the academic track. While the academic track is (strongly and) positively associated with parental attainment (see column 5), it is quite the opposite for the experience-based route (column 2): for both men and women, having less educated parents actually increases the likelihood of certification via work experience.

The parameters in Tables 2 and 3 are not necessarily causal effects of parental education. However, when we condition on dropouts at age 25 , the role of unobserved common factors driving education in both generations is less clear than for education among youth. For example, dropouts with highly educated parents are likely to hold other characteristics or face constraints that hamper adult completion, simply because they have not completed as expected by age 25 .

Our evidence clearly documents that adults who acquire upper secondary qualifications have less favorable parental education than those who complete before age 25 . The vocational routes are particularly important in explaining why the social gradient declines with age. This conclusion is however based on a parsimonious model where (i) educational attainment of both parents are equally important, (ii) marginal effects of more educated parents are constant, and (iii) other family characteristics are left out of the equation. In the next section, we extend the framework along each of these dimensions in order to address whether our results are robust to such specification issues.

\section{Extensions and Robustness Checks}

\subsection{Education of Mother vs. Father}

In Table 4, we relax the assumption that mothers and fathers are equally important for completion of upper secondary education, and report estimates from an extended regression model where attainment of each parent enters additively. The first two columns replicate the specifications of Table 2, columns 1 and 2, allowing the coefficients of mother and father's schooling to take different values. Importantly, whether we consider the attainment of the mother or the father, the key mes- 
Table 3. Completion of upper secondary education, age 40. Conditional on dropout age 25.

Completion age 40 by adult route

Completed age 40 Experience based Apprentice School-based vocational Academic track

(1)

(2)

(3)

(4)

(5)

\begin{tabular}{|c|c|c|c|c|c|}
\hline \multicolumn{6}{|l|}{ A. Men } \\
\hline \multirow[t]{2}{*}{ Parental educ } & $0.0115^{* * *}$ & $-0.0039 * * *$ & $0.0009 * * *$ & 0.0002 & $0.0144 * * *$ \\
\hline & $(0.0007)$ & $(0.0005)$ & $(0.0003)$ & $(0.0002)$ & $(0.0005)$ \\
\hline Adj $R^{\wedge} 2$ & 0.0091 & 0.0020 & 0.0003 & 0.0000 & 0.0316 \\
\hline Observations & 29960 & 29960 & 29960 & 29960 & 29960 \\
\hline Mean dep var & 0.255 & 0.111 & 0.040 & 0.009 & 0.095 \\
\hline \multicolumn{6}{|l|}{ B. Women } \\
\hline \multirow[t]{2}{*}{ Parental educ } & $0.0140 * * *$ & $-0.0032 * * *$ & -0.0003 & $-0.0020 * * *$ & $0.0194 * * *$ \\
\hline & $(0.0009)$ & $(0.0005)$ & $(0.0003)$ & $(0.0002)$ & $(0.0007)$ \\
\hline Adj $R^{\wedge} 2$ & 0.0097 & 0.0017 & 0.0000 & 0.0006 & 0.0314 \\
\hline Observations & 25993 & 25993 & 25993 & 25993 & 25993 \\
\hline Mean dep var & 0.346 & 0.072 & 0.033 & 0.078 & 0.162 \\
\hline
\end{tabular}

Notes: $* * * / * * *$ statistically significant at $10 / 5 / 1 \%$ level. Standard errors are reported in parentheses.

sage from the prior section persists-the relationship between parental education and offspring completion attenuates between ages 25 and 40 . According to the estimates in Table 4, for men the role of mother's attainment declines by $17 \%$ and that of father's attainment by $20 \%$ (compared to the overall decline of $18 \%$ in Table 2 ). For women, the relationships attenuate by $27 \%$ (mother) and $29 \%$ (father), compared to $28 \%$ in Table 2.

The last four columns of Table 4 examine completion by adult route for dropouts at age 25. Again, the chief lesson from the baseline model prevails-the experience-based route reduces the social gradient most strongly. Whether we consider male or female dropouts, or schooling of the mother or the father, parental attain- ment exhibits a statistically significant, negative relationship with acquisition of qualifications via the experiencebased route. Conversely, for dropouts, adult completion through the academic track relates positively to parental attainment, whether of the mother or the father.

The estimates in columns 1 and 2 indicate that schooling of the mother has a greater influence on female completion than schooling of the father. This conclusion rests on the particular metric used, however. As Table 1 showed, years of schooling exhibit much less variation across mothers than fathers, and when we evaluate the influence of parental education in terms of standard deviations, results show the same relationship with mother and father's schooling. To illustrate, at age 40, a one

Table 4. Completion of upper secondary education: mother's vs. father's years of schooling.

\begin{tabular}{|c|c|c|c|c|c|c|}
\hline & \multirow[b]{2}{*}{$\begin{array}{l}\text { Completed } \\
\text { age } 25 \\
\text { (1) }\end{array}$} & \multirow[b]{2}{*}{$\begin{array}{l}\text { Completed } \\
\text { age } 40 \\
(2)\end{array}$} & \multicolumn{4}{|c|}{ Completion age 40 by adult route among dropouts } \\
\hline & & & $\begin{array}{c}\text { Experience } \\
\text { based } \\
\text { (3) }\end{array}$ & $\begin{array}{c}\text { Apprentice } \\
\text { (4) }\end{array}$ & $\begin{array}{l}\text { School-based } \\
\text { vocational } \\
\text { (5) }\end{array}$ & $\begin{array}{c}\text { Academic } \\
\text { track } \\
(6)\end{array}$ \\
\hline \multicolumn{7}{|l|}{ A. Men } \\
\hline Mother educ & $\begin{array}{l}0.0233^{* * *} \\
(0.0006)\end{array}$ & $\begin{array}{l}0.0194^{* * *} \\
(0.0005)\end{array}$ & $\begin{array}{c}-0.0034 * * * \\
(0.0010)\end{array}$ & $\begin{array}{c}0.0002 \\
(0.0006)\end{array}$ & $\begin{array}{c}-0.0003 \\
(0.0003)\end{array}$ & $\begin{array}{l}0.0178 * * * \\
(0.0009)\end{array}$ \\
\hline Father educ & $\begin{array}{l}0.0236^{* * *} \\
(0.0005)\end{array}$ & $\begin{array}{l}0.0189 * * * \\
(0.0004)\end{array}$ & $\begin{array}{c}-0.0043^{* * *} \\
(0.0008)\end{array}$ & $\begin{array}{l}0.0015^{* * *} \\
(0.0005)\end{array}$ & $\begin{array}{c}0.0005^{*} \\
(0.0003)\end{array}$ & $\begin{array}{l}0.0118 * * * \\
(0.0008)\end{array}$ \\
\hline Adj $R^{\wedge} 2$ & 0.0658 & 0.0545 & 0.0020 & 0.0003 & 0.0001 & 0.0321 \\
\hline Observations & 125207 & 125207 & 29960 & 29960 & 29960 & 29960 \\
\hline \multicolumn{7}{|l|}{ B. Women } \\
\hline Mother educ & $\begin{array}{l}0.0264 * * * \\
(0.0005)\end{array}$ & $\begin{array}{l}0.0193^{* * *} \\
(0.0005)\end{array}$ & $\begin{array}{c}-0.0046^{* * *} \\
(0.0010)\end{array}$ & $\begin{array}{c}0.0005 \\
(0.0007)\end{array}$ & $\begin{array}{l}-0.0042 * * * \\
(0.0010)\end{array}$ & $\begin{array}{l}0.0264^{* * *} \\
(0.0013)\end{array}$ \\
\hline Father educ & $\begin{array}{l}0.0227^{* * *} \\
(0.0005)\end{array}$ & $\begin{array}{l}0.0162^{* * *} \\
(0.0004)\end{array}$ & $\begin{array}{c}-0.0022^{* * *} \\
(0.0008)\end{array}$ & $\begin{array}{c}-0.0009 * \\
(0.0005)\end{array}$ & $\begin{array}{c}-0.0004 \\
(0.0008)\end{array}$ & $\begin{array}{l}0.0144^{* * *} \\
(0.0011)\end{array}$ \\
\hline Adj $R^{\wedge} 2$ & 0.0754 & 0.0547 & 0.0017 & 0.0000 & 0.0008 & 0.0327 \\
\hline Observations & 121127 & 121127 & 25993 & 25993 & 25993 & 25993 \\
\hline
\end{tabular}

Notes: $* * * / * * *$ Statistically significant at $10 / 5 / 1 \%$ level. Standard errors are reported in parentheses. 
standard deviation increase in either mother or father's schooling increases the completion rate of daughters by 4.7 percentage points. The only finding in Table 4 that is invariant to standardization of parental schooling is the result in column 6 . For dropouts, the attainment of the mother is more important than that of the father for adult completion of upper secondary education through the academic track.

\subsection{Decreasing Returns to Parental Education?}

Our baseline model assumes that parental education predicts offspring completion linearly, but, as the binned scatter plots in Figure 4 show, the data reveal a clear pattern of decreasing returns. The increase in the completion rate associated with an additional year of parental education declines when parents are highly educated. Our main interest, however, is the role of completion during adulthood and we see from the figure that marginal effects of parental education are lower (the curve is flatter) at age 40 than age 25 . To account for decreasing marginal effects of parental education, we replace the linear model with a second order polynomial of parental attainment. In Table A2 in the Appendix, we report marginal effects of parental education evaluated at median parental attainment and find that the decline in the social gradient is similar to that revealed by the baseline, linear model.

Figure 5 displays binned scatter plots in the sample of dropouts at age 25 , comparing the alternative routes to adult qualifications. There is little indication that the linearity assumption is not justified and Table A2 con-

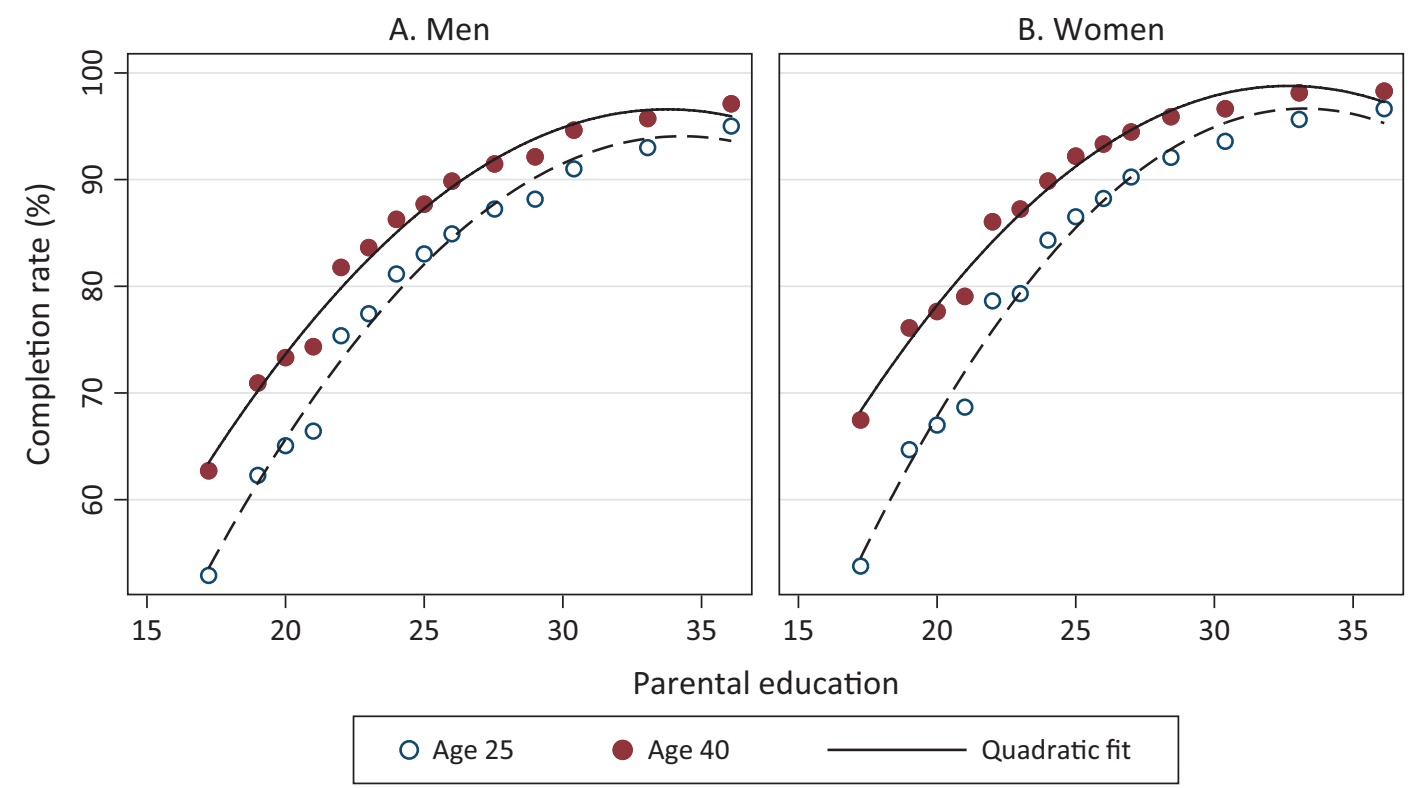

Figure 4. Binned scatter plots of relationship between parental attainment and completion of upper secondary education, by age and gender.
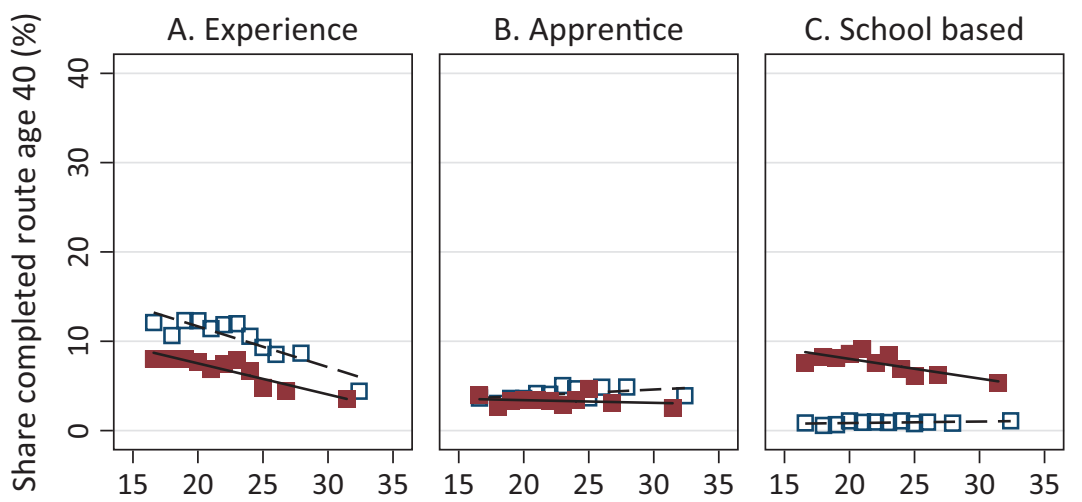

D. Academic

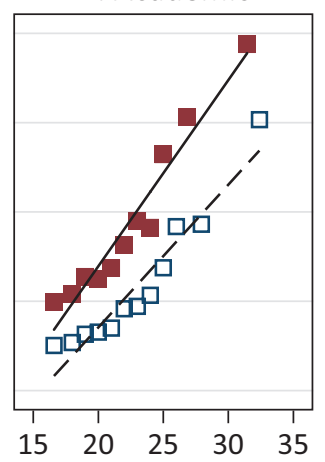

Parental education

$\square$ Men $\quad$ Women Linear fit

Figure 5. Adult completion of upper secondary education and parental education. Binned scatter plots by route of completion. Note: Samples consist of dropouts age 25, observation counts are 29,960 men and 25,993 women. 
firms previous results. Evaluated at the median, an additional year of parental education is associated with a lower probability of experience-based vocational qualifications, while completion through the academic track is more likely. The point estimates are comparable to those of the linear model reported in Table 3. This shows that our conclusions do not hinge on the assumption of a constant marginal effect of parental education.

\subsection{Accounting for Other Family Background Characteristics}

Family background is more than parental education. Next, we check whether our findings are robust to an extended representation of family background, addressing the question of whether parental education simply reflects other characteristics. In Table A3 in the Appendix, columns 1 and 2, we compare the associations between parental attainment and completion at ages 25 and 40, controlling for other commonly used indicators on family background such as parental earnings, age at childbirth, marital status, and municipality of residence at age 19. Not surprisingly, the parental education coefficients are moderately lower than those in Table 2 but remain statistically significant and the relative attenuation between age 25 and 40 is of similar magnitude to that in Table 2. Further, the pattern of lower coefficients (i.e., lower social gradient) at age 40 extends to other family characteristics like parental earnings and marital status. Finally, as in Table 2, there is a distinct decline in the adjusted R-squared from age 25 to age 40, showing a reduction in the overall association between completion of upper secondary education and parental background characteristics.

In the sample of dropouts at age 25, the patterns of Table 3 remain unaffected by the inclusion of other family characteristics (see Table A3, columns 3 to 6 ). While dropouts with low educated parents are more likely to acquire experience-based qualifications, they are less likely to complete through the academic track. Higher parental earnings raise the probability of academic qualifications but is unrelated to vocational qualifications acquired through work experience.

\section{Discussion and Conclusion}

Youth who do not complete upper secondary education disproportionately have parents with low educational attainment (see, e.g., Rumberger, 1987). For youths our study confirms prior evidence (Hansen, 1997): even in the relatively uniform Norwegian education system with high completion rates, there is a strong social gradient in educational attainment. For example, we find that, at age 25 , one more year of parental education is associated with an increase in upper secondary completion by $2.4 \%$ for both men and women.

Our focus is on the role played by institutions that offer opportunities for adults to complete upper sec- ondary education. Does adult attainment reduce initial social differences in education, or does it reinforce such differences? Our main contribution has been to document differential patterns across alternative routes to adult qualifications and, in particular, to analyze the role of routes based on workplace learning. Using individual panels from administrative registers, we study upper secondary completion through age 40 for five birth cohorts (1973-1977). We find that the influence of parental education on upper secondary completion declines with age, meaning that the total qualifying activity for adults does mitigate social gradients. At age $\mathbf{4 0}$ one more year of parental education is associated with an increase in upper secondary completion of $1.9 \%$ and $1.8 \%$ for men and women respectively-still a substantial correlation, but significantly lower than at age 25 . Adults who complete upper secondary education for the first time come more often from families with high educational attainment compared to those who do not complete by age 40 , but less so than those who complete as youths.

An important finding is that alternative routes to upper secondary qualifications recruit from different family education backgrounds. The experience-based route unequivocally lowers the social gradient as completion through the route is negatively correlated with parental education, both in the total sample (Table 2) and when we condition the sample on those who did not complete secondary education by age 25 (Table 3 ). In its absence, many of those who acquire qualifications through this route would likely not complete upper secondary education at all (for a qualitative study of adults who complete this route see Aspøy \& Tønder, 2017). For men, the experience-based route explains $74 \%$ of the reduction of the correlation between parental education and attainment between ages 25 and 40 . For women, the figure is $31 \%$. It is reasonable to attribute the special recruitment pattern of the experience-based route to the low threshold it establishes. The experience-based route builds on informally gained competence at the workplace and does not require re-entry into the classroom or self-studying. Previous research indicates that such requirements represent a strong barrier to entry for individuals with a low-education family background (see, e.g., Illeris, 2006). A second route based on learning at work, adult apprenticeships, is similar to the experiencebased route in that it does not require extensive re-entry into classroom settings, but it still entails an active decision to enter training for a prolonged period. This route does not have the same low parental education selection profile as the experience-based route but is not particularly associated with high parental education either. The same is true for the now marginal school-based vocational routes, although for women without upper secondary qualifications at age 25 , the route does correlate with low parental education. Among dropouts at age 25, adult completion through the academic track correlates clearly with a high parental education background. It is interesting to note that each of the four alternative routes 
still contributes to a weakening of the social gradient from age 25 to 40, even the academic track, because the correlation with parental education is weaker than it is for completion as youths.

At first glance, our evidence appears at odds with prior research suggesting similar social recruitment patterns among adults and youth (Glorieux et al., 2011). Partly this is true; partly the difference is superficial. Like previous research, our study shows that those who complete as adults do have parents with more education than those who never complete upper secondary education. But we also show that adult qualifying activities reduce the social gradient in completion, and as such reduce social inequalities. More importantly, our case differs from previous studies in that we also examine adult education routes based on workplace learning. We show that especially one such route, the experience-based route, has a different social recruitment pattern and attracts adults with low parental education. This institution plays an important role in reducing the social gradient and seems to work differently than institutions studied in prior research. While our conclusion is that all adult routes studied to some extent reduce the social gradient, the experience-based route is the strongest contributor.

Our analysis reveals substantial gender differences. Men use the experience-based route extensively. As mentioned above, completion through the experience-based route explains almost three quarters of the reduction in the correlation with parental education from age 25 to 40, with apprenticeship a distant second. For women, the pattern is more mixed. All qualifying routes reduce the correlation between parental education and attainment from age 25 to 40 . Women qualify more often through the academic track and the school-based vocational route, which explains why both contribute substantially to the reduction in the correlation with age, despite the academic track's association with a higher parental education than the other three routes. The gender patterns relate to gender segregation in the Norwegian education system and labor market. Gender segregation in the education system seems to be stronger in systems with strong vocational education principles linked to occupational labor markets (Imdorf, Hegna, \& Reizel, 2015). In Norway, men choose VET and apprenticeships to a higher degree than women who more often go on to higher education as adults. VET itself is highly gender segregated across fields. School-based vocational tracks have almost exclusively existed in the health care field and have primarily attracted women.

The empirical analysis does not account for "anticipation effects", whereby the existence of adult routes to upper secondary qualifications affects the educational choices of youth. In the US, scholars have documented that access to GED induces dropout among young high school students (Heckman, Humphries, LaFontaine, \& Rodriguez, 2012). However, interviews with individuals who have completed vocational qualifications as adults through the experience-based route show that they were not aware of this route, or indeed any adult route, while they were young (Aspøy \& Tønder, 2017). Generally, studies of school dropouts show that dropout decisions reflect the current life situation of youth, sometimes with little forward calculation of options (e.g., Thrana, 2016).

Our evidence points to favorable effects of policies and institutions that offer opportunities for certification of qualifications acquired at work. There are limitations, however, to what can be achieved with such policies. The experience-based route is, by definition, only available for workers with stable employment. The non-employed need other ways to qualify. Adult apprenticeships also contribute to a lower social gradient in education, although much less than the experience-based route, and is available for individuals previously outside the labor market. A second reservation is that adults going through the experience-based route often are exempted from taking general subjects, which may reduce their capacity to change jobs or industry in response to structural change, but as of yet there are no analyses that substantiate or alleviate such concerns.

\section{Acknowledgments}

We acknowledge financial support from the Norwegian Research Council (projects "Adult Learning, Vocational Skills and Labour Market Outcomes" \#228247 and "The decline in employment and the rise of its social gradient" \#280350). Administrative register data on loan from Statistics Norway have been essential for this project.

\section{Conflict of Interests}

The authors declare no conflict of interests.

\section{References}

Ammermueller, A. (2013). Institutional features of schooling systems and educational inequality: Crosscountry evidence from PIRLS and PISA. German Economic Review, 14(2), 190-213. https://doi.org/10. 1111/j.1468-0475.2012.00565.x

Aspøy, T. M., \& Tønder, A. H. (2017). When work comes first: Young adults in vocational education and training in Norway. International Journal for Research in Vocational Education and Training, 4(3), 270-288. https://doi.org/10.13152/IJRVET.4.3.5

Beicht, U., \& Walden, G. (2015). How socially selective is the German system of initial vocational education and training? Transitions into initial vocational training and the influence of social background. Journal of Vocational Education and Training, 67(2), 235-255. https://doi.org/10.1080/13636820.2014.983955

Blossfeld, H.-P., Buchholz, S., Skopek, J., \& Triventi, M. (2016). Models of secondary education and social inequality: An international comparison. Cheltenham: Edward Elgar. 
Blossfeld, H.-P., Kilpi-Jakonen, E., Vilhena, D. V., \& Buchholz, S. (2014). Adult learning in modern societies. An international comparison from a life course perspective. Cheltenham: Edward Elgar.

Bratsberg, B., Nyen, T., \& Raaum, O. (2017). Fagbrev i voksen alder [Vocational certification in adulthood]. Søkelys på arbeidslivet, 34(1/2), 24-43. https://doi. org/10.18261/issn.1504-7989-2017-01-02-02

Breen, R., Luijkx, R., Müller, W., \& Pollak, R. (2009). Nonpersistent inequality in educational attainment: Evidence from eight European countries. American Journal of Sociology, 114(5), 1475-1521. https://doi.org/ 10.1086/595951

Busemeyer, M., \& Trampusch, C. (2012). The comparative political economy of collective skill formation. In M. Busemeyer \& C. Trampusch (Eds.), The political economy of collective skill formation (pp. 3-38). Oxford: Oxford University Press.

Eurostat. (2018). Educational attainment statistics. Europa.eu. Retrieved from https://ec.europa.eu/ eurostat/statistics-explained/index.php/ Educational_attainment_statistics

Glorieux, I., Heyman, R., Jegers, M., \& Taelman, M. (2011). 'Who takes a second chance?' Profile of participants in alternative systems for obtaining a secondary diploma. International Journal of Lifelong Education, 30(6), 781-794. https://doi.org/10.1080/ 02601370.2011 .627472

Greinert, W. D. (2004). European vocational training "systems": Some thoughts on the theoretical context of their historical development. European Journal of Vocational Training, 32(May/August), 18-25.

Hansen, M. N. (1997). Social and economic inequality in the educational career: Do the effects of social background characteristics decline? European Sociological Review, 13(3), 305-321. https://doi.org/10.1093/ oxfordjournals.esr.a018220

Haveman, R., \& Wolfe, B. (1995). The determinants of children's attainments: A review of methods and findings. Journal of Economic Literature, 33(4), 1829-1878.

Heckman, J. J., Humphries, J. E., LaFontaine, P. A., \& Rodriguez, P. L. (2012). How the GED testing program induces students to drop out. Journal of Labor Economics, 30(3), 495-520. https://doi.org/10.3386/ w14044

Heckman, J. J., Humphries, J. E., \& Mader, N. S. (2010). The GED (NBER Working Paper 16064). Cambridge, MA: National Bureau of Economic Research. https:// doi.org/10.3386/w16064

Hertz, T., Jaysundera, T., Piraino, P., Selcuk, S., Smith, N., $\&$ Verashchagina, A. (2007). The inheritance of educational inequality: International comparisons and fiftyyear trends. The B.E. Journal of Economic Analysis and Policy, 7(2). https://doi.org/10.2202/1935-1682. 1775

Holmlund, H., Lindahl, M., \& Plug, E. (2011). The causal effect of parents' schooling on children's schooling:
A comparison of estimation methods. Journal of Economic Literature, 49(3), 615-651. https://doi.org/10. 1257/jel.49.3.615

Illeris, K. (2004). Adult education and adult learning. Malabar, FL: Krieger Publishing.

Illeris, K. (2006). What is special about adult learning? In P. Sunderland \& J. Crowther (Eds.), Lifelong Learning. Concepts and contexts (pp. 15-23). London: Routledge.

Imdorf, C., Hegna, K., \& Reizel, L. (2015). Educational systems and gender segregation in education: $A$ three-country comparison of Germany, Norway and Canada. In C. Imdorf, K. Hegna, \& L. Reisel (Eds.), Gender segregation in vocational education (pp. 83-122). Bingley: Emerald Group Publishing Limited.

Knowles, M. (1978). The adult learner: A neglected species. Houston, TX: Gulf Publishing Co.

Müller, W., \& Karle, W. (1993). Social selection in educational systems in Europe. European Sociological Review, 9(1), 1-23. http://dx.doi.org/10.1093/ oxfordjournals.esr.a036652

Nyen, T., Skålholt, A., \& Tønder, A. H. (2015). Fagopplæring som vei inn i arbeidslivet [Vocational education and training as a pathway to work]. In H. Høst (Ed.), Kvalitet i fag-og yrkesopplæringen. Sluttrapport [Quality of vocational education and training. Final report] (pp. 173-229). Oslo: NIFU.

Nyen, T., \& Tønder, A. H. (2014). Yrkesfagene under press [Vocational trades under pressure]. Oslo: Universitetsforlaget.

OECD. (2014). Indicator A2: How many students are expected to complete upper secondary education? Paris: OECD Publishing. http://dx.doi.org/10.1787/ 888933115122

Olsen, O. J., Høst, H., \& Michelsen, S. (2008). Veier fra yrkesopplæring til arbeidslivet. En studie av det norske overgangsregimets effektivitet [Pathways from vocational education and training into work. A study of the efficiency of the Norwegian transition regime]. In J. Olofsson \& A. Panican (Eds.), Ungdomars väg från skole til arbetsliv. Nordiska erfarenheter [Youths' transition from school to work. Nordic experiences] (pp. 249-332). København: Nordisk ministerråd.

Powell, J., \& Solga, H. (2011). Why are higher education participation rates in Germany so low? Institutional barriers to higher education expansion. Journal of Education and Work, 24(1/2), 49-68. http://dx.doi.org/ 10.1080/13639080.2010.534445

Rumberger, R. W. (1987). High school dropouts: A review of issues and evidence. Review of Educational Research, 57(2), 101-121. http://dx.doi.org/10.2307/ 1170232

Shavit, Y., \& Müller, W. (2006). Vocational secondary education, tracking and social stratification. In M. Hallinan (Ed.), Handbook in the sociology of education (pp. 437-452). New York, NY: Springer.

Thrana, H. M. (2016). Ungdommens forklaringer på hvor- 
for de ikke fullfører videregående opplæring [Youths' explanations why they do not complete upper secondary education]. In K. Reegård \& J. Rogstad (Eds.),
De frafalne. Om frafall i videregående opplæring [The dropouts: On dropout from upper secondary education]. Oslo: Gyldendal Akademisk.

\section{About the Authors}

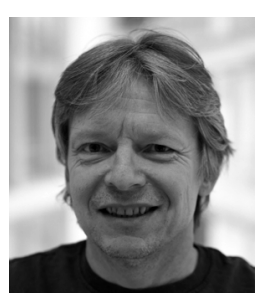

Bernt Bratsberg holds a PhD in Economics from University of California, Santa Barbara, and is a Senior Research Fellow at the Ragnar Frisch Centre for Economic Research. His main research areas are immigration, economic inequality, and education.

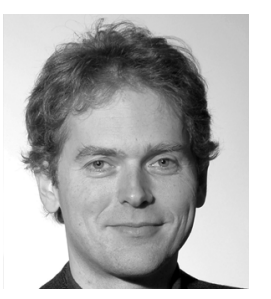

Torgeir Nyen is a Political Scientist at the independent social science research foundation FAFO, based in Oslo. His main research interests are within vocational education and training and education policy.

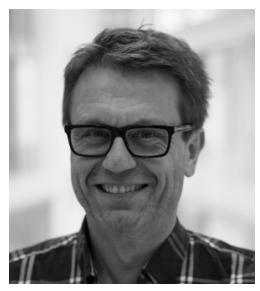

Oddbjørn Raaum holds a PhD in Economics from the University of Oslo and is a Senior Research Fellow at the Ragnar Frisch Centre for Economic Research. His main research areas are migration, inequality, intergenerational mobility and education. 


\section{Appendix}

\section{Supplementary descriptive statistics and empirical results}

Table A1. Top five fields of study by adult route to completion of upper secondary education.

\begin{tabular}{lccc}
\hline Experience based & Adult apprentice & School-based vocational & Academic track \\
\hline A. Men & & & \\
$4579016.8 \%$ & $45712912.7 \%$ & $46120127.7 \%$ & $4011018.4 \%$ \\
Constr machine oper & Carpentry & Nursing aux skills & General subjects \\
$4571296.5 \%$ & $4551039.6 \%$ & $4551387.8 \%$ & $4011102.6 \%$ \\
Carpentry & Electr engineering & Comp electr level 4 & Suppl university admis \\
$4541025.2 \%$ & $4571219.0 \%$ & $4799015.5 \%$ & $6221012.6 \%$ \\
Transp terminal oper & Plumbing & Agriculture & Teacher \\
$4819055.0 \%$ & $4552043.9 \%$ & $4551284.1 \%$ & $6611202.6 \%$ \\
Logistics & Mechanic, light motor & Comp electr level 3 & Nursing \\
$4814014.5 \%$ & $4571183.4 \%$ & $4619033.4 \%$ & $6613051.9 \%$ \\
Transport driver & Painting & Health work & Social educator \\
$\mathrm{N}=3327$ & $\mathrm{~N}=1200$ & $\mathrm{~N}=271$ & $\mathrm{~N}=2843$ \\
\hline B. Women & & & $66112011.8 \%$ \\
$46210129.8 \%$ & $46190224.0 \%$ & $46120156.6 \%$ & Nursing \\
Child care youth work & Care work & Nursing aux skills & $4011019.2 \%$ \\
$46990713.8 \%$ & $46210121.7 \%$ & $46990818.1 \%$ & General subjects \\
Institutional cleaning & Child care youth work & Medical secretary & $6211056.3 \%$ \\
$46190312.8 \%$ & $4831019.0 \%$ & $4642013.9 \%$ & Pre-school teacher \\
Health work & Ladies' hairdressing & Dental assistant & $6613054.1 \%$ \\
$4619029.8 \%$ & $4581065.3 \%$ & $4663013.9 \%$ & Social educator \\
Care work & Institutional cookery & Pharmacy skills & $6221013.8 \%$ \\
$4421014.5 \%$ & $4619034.6 \%$ & $4619033.0 \%$ & Teacher \\
Retailing & Health work & Health work & $\mathrm{N}=4214$ \\
$\mathrm{~N}=1865$ & $\mathrm{~N}=866$ & $\mathrm{~N}=2038$ & \\
\hline
\end{tabular}

Notes: Six-digit code refers to the Norwegian Standard Classification of Education (NUS2000). One field of study, 461903 Health work, appears in both the apprentice and school-based categories. Within this field, those classified in the school category had their training in school.

Table A2. Completion of upper secondary education; quadratic specification of parental years of schooling.

\begin{tabular}{|c|c|c|c|c|c|c|}
\hline & \multirow[b]{2}{*}{$\begin{array}{l}\text { Completed } \\
\text { age } 25 \\
\text { (1) }\end{array}$} & \multirow[b]{2}{*}{$\begin{array}{l}\text { Completed } \\
\text { age } 40 \\
(2)\end{array}$} & \multicolumn{4}{|c|}{ Completion age 40 by adult route } \\
\hline & & & $\begin{array}{c}\text { Experience } \\
\text { based } \\
\text { (3) }\end{array}$ & $\begin{array}{c}\text { Apprentice } \\
\text { (4) }\end{array}$ & $\begin{array}{l}\text { School-based } \\
\text { vocational } \\
\text { (5) }\end{array}$ & $\begin{array}{l}\text { Academic } \\
\text { track } \\
(6)\end{array}$ \\
\hline \multicolumn{7}{|l|}{ A. Men } \\
\hline Parent ed-23 & $\begin{array}{l}0.0315^{* * *} \\
(0.0003)\end{array}$ & $\begin{array}{l}0.0261^{* * *} \\
(0.0003)\end{array}$ & $\begin{array}{c}-0.0034 * * * \\
(0.0005)\end{array}$ & $\begin{array}{l}0.0011^{* * *} \\
(0.0003)\end{array}$ & $\begin{array}{c}0.0002 \\
(0.0002)\end{array}$ & $\begin{array}{l}0.0134^{* * *} \\
(0.0005)\end{array}$ \\
\hline$($ Par ed-23)^2 & $\begin{array}{c}-0.0014 * * * \\
(0.0000)\end{array}$ & $\begin{array}{c}-0.0012 * * * \\
(0.0000)\end{array}$ & $\begin{array}{c}-0.0003 * * * \\
(0.0001)\end{array}$ & $\begin{array}{c}-0.0001^{* *} \\
(0.0001)\end{array}$ & $\begin{array}{c}-0.0000 \\
(0.0000)\end{array}$ & $\begin{array}{l}0.0007^{* * *} \\
(0.0001)\end{array}$ \\
\hline Adj $R^{\wedge} 2$ & 0.0744 & 0.0624 & 0.0025 & 0.0004 & 0.0000 & 0.0340 \\
\hline Observations & 125207 & 125207 & 29960 & 29960 & 29960 & 29960 \\
\hline \multicolumn{7}{|l|}{ B. Women } \\
\hline Parent ed-23 & $\begin{array}{l}0.0337^{* * *} \\
(0.0003)\end{array}$ & $\begin{array}{l}0.0248^{* * *} \\
(0.0003)\end{array}$ & $\begin{array}{c}-0.0031^{* * *} \\
(0.0005)\end{array}$ & $\begin{array}{c}-0.0003 \\
(0.0003)\end{array}$ & $\begin{array}{c}-0.0019 * * * \\
(0.0005)\end{array}$ & $\begin{array}{l}0.0191 * * * \\
(0.0007)\end{array}$ \\
\hline$($ Par ed-23)^2 & $\begin{array}{c}-0.0017^{* * *} \\
(0.0000)\end{array}$ & $\begin{array}{c}-0.0013^{* * *} \\
(0.0000)\end{array}$ & $\begin{array}{c}-0.0002^{*} \\
(0.0001)\end{array}$ & $\begin{array}{c}-0.0000 \\
(0.0001)\end{array}$ & $\begin{array}{l}-0.0002 * * * \\
(0.0001)\end{array}$ & $\begin{array}{l}0.0006 * * * \\
(0.0001)\end{array}$ \\
\hline Adj $R^{\wedge} 2$ & 0.0878 & 0.0650 & 0.0018 & 0.0000 & 0.0009 & 0.0325 \\
\hline Observations & 121127 & 121127 & 25993 & 25993 & 25993 & 25993 \\
\hline
\end{tabular}

Notes: $* * * / * * *$ statistically significant at $10 / 5 / 1 \%$ level. Standard errors are reported in parentheses. The median parental schooling in the sample is 23 . 
Table A3. Completion of upper secondary education; extended parental background characteristics.

\begin{tabular}{|c|c|c|c|c|c|c|}
\hline & \multirow[b]{2}{*}{$\begin{array}{l}\text { Completed } \\
\text { age } 25 \\
\text { (1) }\end{array}$} & \multirow[b]{2}{*}{$\begin{array}{l}\text { Completed } \\
\text { age } 40 \\
(2)\end{array}$} & \multicolumn{4}{|c|}{ Completion age 40 by adult route } \\
\hline & & & $\begin{array}{c}\text { Experience } \\
\text { based } \\
(3)\end{array}$ & $\begin{array}{c}\text { Apprentice } \\
\text { (4) }\end{array}$ & $\begin{array}{c}\text { School-based } \\
\text { vocational } \\
\text { (5) }\end{array}$ & $\begin{array}{c}\text { Academic } \\
\text { track } \\
(6)\end{array}$ \\
\hline \multicolumn{7}{|l|}{ A. Men } \\
\hline Parental ed & $\begin{array}{l}0.0268 * * * \\
(0.0004)\end{array}$ & $\begin{array}{l}0.0225 * * * \\
(0.0003)\end{array}$ & $\begin{array}{c}-0.0026 * * * \\
(0.0006)\end{array}$ & $\begin{array}{c}0.0009 * * \\
(0.0004)\end{array}$ & $\begin{array}{c}0.0002 \\
(0.0002)\end{array}$ & $\begin{array}{l}0.0122 * * * \\
(0.0005)\end{array}$ \\
\hline$(\text { Par ed })^{\wedge} 2$ & $\begin{array}{l}-0.0014^{* * *} \\
(0.0000)\end{array}$ & $\begin{array}{l}-0.0012^{* * * *} \\
(0.0000)\end{array}$ & $\begin{array}{l}-0.0003 * * * \\
(0.0001)\end{array}$ & $\begin{array}{l}-0.0001^{* * *} \\
(0.0001)\end{array}$ & $\begin{array}{c}-0.0000 \\
(0.0000)\end{array}$ & $\begin{array}{l}0.0006^{* * *} \\
(0.0001)\end{array}$ \\
\hline Par earnings & $\begin{array}{l}0.0110 * * * \\
(0.0004)\end{array}$ & $\begin{array}{l}0.0094 * * * \\
(0.0004)\end{array}$ & $\begin{array}{c}0.0004 \\
(0.0007)\end{array}$ & $\begin{array}{l}0.0011^{* * *} \\
(0.0004)\end{array}$ & $\begin{array}{c}-0.0001 \\
(0.0002)\end{array}$ & $\begin{array}{l}0.0030 * * * \\
(0.0006)\end{array}$ \\
\hline$(\text { Par earn })^{\wedge} 2$ & $\begin{array}{l}-0.0002^{* * *} \\
(0.0000)\end{array}$ & $\begin{array}{l}-0.0001 * * * \\
(0.0000)\end{array}$ & $\begin{array}{c}-0.0001^{*} \\
(0.0000)\end{array}$ & $\begin{array}{c}-0.0000 \\
(0.0000)\end{array}$ & $\begin{array}{c}-0.0000 \\
(0.0000)\end{array}$ & $\begin{array}{l}0.0001^{* * *} \\
(0.0000)\end{array}$ \\
\hline Mother age & $\begin{array}{l}0.0040^{* * *} \\
(0.0004)\end{array}$ & $\begin{array}{l}0.0033^{* * *} \\
(0.0004)\end{array}$ & $\begin{array}{c}0.0000 \\
(0.0006)\end{array}$ & $\begin{array}{c}0.0001 \\
(0.0004)\end{array}$ & $\begin{array}{c}-0.0001 \\
(0.0002)\end{array}$ & $\begin{array}{l}0.0012 * * \\
(0.0006)\end{array}$ \\
\hline$(\mathrm{M} \text { age })^{\wedge} 2$ & $\begin{array}{l}-0.0002 * * * \\
(0.0000)\end{array}$ & $\begin{array}{c}-0.0001 * * * \\
(0.0000)\end{array}$ & $\begin{array}{c}-0.0001 \\
(0.0001)\end{array}$ & $\begin{array}{c}0.0000 \\
(0.0000)\end{array}$ & $\begin{array}{c}0.0000 \\
(0.0000)\end{array}$ & $\begin{array}{c}0.0000 \\
(0.0001)\end{array}$ \\
\hline Father age & $\begin{array}{l}0.0014^{* * *} \\
(0.0004)\end{array}$ & $\begin{array}{l}0.0012^{* * *} \\
(0.0004)\end{array}$ & $\begin{array}{c}0.0005 \\
(0.0006)\end{array}$ & $\begin{array}{c}0.0003 \\
(0.0004)\end{array}$ & $\begin{array}{c}0.0002 \\
(0.0002)\end{array}$ & $\begin{array}{c}-0.0005 \\
(0.0005)\end{array}$ \\
\hline$(\text { Fath age })^{\wedge} 2$ & $\begin{array}{c}0.0000 \\
(0.0000)\end{array}$ & $\begin{array}{c}0.0000 \\
(0.0000)\end{array}$ & $\begin{array}{c}-0.0000 \\
(0.0000)\end{array}$ & $\begin{array}{c}0.0000 \\
(0.0000)\end{array}$ & $\begin{array}{c}-0.0000 \\
(0.0000)\end{array}$ & $\begin{array}{c}0.0000 \\
(0.0000)\end{array}$ \\
\hline Par married & $\begin{array}{l}0.1141^{* * *} \\
(0.0042)\end{array}$ & $\begin{array}{l}0.0913^{* * *} \\
(0.0038)\end{array}$ & $\begin{array}{l}0.0252 * * * \\
(0.0057)\end{array}$ & $\begin{array}{c}0.0011 \\
(0.0035)\end{array}$ & $\begin{array}{c}-0.0036 * * \\
(0.0017)\end{array}$ & $\begin{array}{c}-0.0069 \\
(0.0052)\end{array}$ \\
\hline Par divorced & $\begin{array}{l}-0.0207^{* * *} \\
(0.0048)\end{array}$ & $\begin{array}{l}-0.0123 * * * \\
(0.0043)\end{array}$ & $\begin{array}{l}0.0127^{* *} \\
(0.0061)\end{array}$ & $\begin{array}{c}0.0010 \\
(0.0038)\end{array}$ & $\begin{array}{c}-0.0047^{* *} \\
(0.0018)\end{array}$ & $\begin{array}{c}-0.0063 \\
(0.0056)\end{array}$ \\
\hline Adj $R^{\wedge} 2$ & 0.1171 & 0.0979 & 0.0181 & 0.0085 & 0.0018 & 0.0418 \\
\hline Observations & 124957 & 124957 & 29887 & 29887 & 29887 & 29887 \\
\hline \multicolumn{7}{|l|}{ B. Women } \\
\hline Parental ed & $\begin{array}{l}0.0289 * * * \\
(0.0004)\end{array}$ & $\begin{array}{l}0.0218^{* * * *} \\
(0.0003)\end{array}$ & $\begin{array}{l}-0.0027^{* * *} \\
(0.0005)\end{array}$ & $\begin{array}{c}0.0000 \\
(0.0004)\end{array}$ & $\begin{array}{c}-0.0014 * * * \\
(0.0006)\end{array}$ & $\begin{array}{l}0.0184 * * * \\
(0.0008)\end{array}$ \\
\hline$(\text { Par ed })^{\wedge} 2$ & $\begin{array}{l}-0.0017^{* * *} \\
(0.0000)\end{array}$ & $\begin{array}{l}-0.0013^{* * *} \\
(0.0000)\end{array}$ & $\begin{array}{c}-0.0001 \\
(0.0001)\end{array}$ & $\begin{array}{c}0.0000 \\
(0.0001)\end{array}$ & $\begin{array}{l}-0.0002^{* * *} \\
(0.0001)\end{array}$ & $\begin{array}{l}0.0005 * * * \\
(0.0001)\end{array}$ \\
\hline Par earnings & $\begin{array}{l}0.0116^{* * * *} \\
(0.0004)\end{array}$ & $\begin{array}{l}0.0088^{* * * *} \\
(0.0004)\end{array}$ & $\begin{array}{c}0.0003 \\
(0.0006)\end{array}$ & $\begin{array}{c}0.0000 \\
(0.0004)\end{array}$ & $\begin{array}{c}0.0003 \\
(0.0006)\end{array}$ & $\begin{array}{l}0.0039 * * * \\
(0.0008)\end{array}$ \\
\hline$(\text { Par earn })^{\wedge} 2$ & $\begin{array}{c}-0.0003^{* * *} \\
(0.0000)\end{array}$ & $\begin{array}{c}-0.0002 * * * \\
(0.0000)\end{array}$ & $\begin{array}{c}-0.0002^{* *} \\
(0.0001)\end{array}$ & $\begin{array}{c}-0.0000 \\
(0.0001)\end{array}$ & $\begin{array}{c}-0.0000 \\
(0.0001)\end{array}$ & $\begin{array}{c}-0.0000 \\
(0.0001)\end{array}$ \\
\hline Mother age & $\begin{array}{l}0.0052^{* * *} \\
(0.0004)\end{array}$ & $\begin{array}{l}0.0033^{* * *} \\
(0.0004)\end{array}$ & $\begin{array}{c}0.0008 \\
(0.0005)\end{array}$ & $\begin{array}{c}0.0002 \\
(0.0004)\end{array}$ & $\begin{array}{c}-0.0002 \\
(0.0006)\end{array}$ & $\begin{array}{c}-0.0007 \\
(0.0008)\end{array}$ \\
\hline$(\mathrm{M} \text { age })^{\wedge} 2$ & $\begin{array}{l}-0.0002 * * * \\
(0.0000)\end{array}$ & $\begin{array}{l}-0.0001^{* * *} \\
(0.0000)\end{array}$ & $\begin{array}{c}-0.0001 \\
(0.0001)\end{array}$ & $\begin{array}{c}0.0000 \\
(0.0000)\end{array}$ & $\begin{array}{c}-0.0000 \\
(0.0001)\end{array}$ & $\begin{array}{c}0.0001 \\
(0.0001)\end{array}$ \\
\hline Father age & $\begin{array}{c}0.0006 \\
(0.0004)\end{array}$ & $\begin{array}{c}0.0006 * \\
(0.0003)\end{array}$ & $\begin{array}{c}-0.0006 \\
(0.0005)\end{array}$ & $\begin{array}{c}-0.0001 \\
(0.0004)\end{array}$ & $\begin{array}{c}0.0001 \\
(0.0005)\end{array}$ & $\begin{array}{c}0.0014 * \\
(0.0007)\end{array}$ \\
\hline$(\text { Fath age })^{\wedge} 2$ & $\begin{array}{c}0.0000 \\
(0.0000)\end{array}$ & $\begin{array}{c}0.0000 * \\
(0.0000)\end{array}$ & $\begin{array}{c}0.0000 \\
(0.0000)\end{array}$ & $\begin{array}{c}0.0000 \\
(0.0000)\end{array}$ & $\begin{array}{c}0.0000 \\
(0.0000)\end{array}$ & $\begin{array}{c}0.0000 \\
(0.0000)\end{array}$ \\
\hline Par married & $\begin{array}{l}0.0982^{* * *} \\
(0.0041)\end{array}$ & $\begin{array}{l}0.0609 * * * \\
(0.0035)\end{array}$ & $\begin{array}{c}0.0089 * \\
(0.0049)\end{array}$ & $\begin{array}{c}-0.0042 \\
(0.0034)\end{array}$ & $\begin{array}{c}0.0000 \\
(0.0052)\end{array}$ & $\begin{array}{c}-0.0160 * * \\
(0.0070)\end{array}$ \\
\hline Par divorced & $\begin{array}{c}-0.0107^{* *} \\
(0.0046)\end{array}$ & $\begin{array}{l}-0.0116^{* * *} \\
(0.0040)\end{array}$ & $\begin{array}{c}-0.0040 \\
(0.0053)\end{array}$ & $\begin{array}{c}-0.0015 \\
(0.0037)\end{array}$ & $\begin{array}{c}-0.0065 \\
(0.0056)\end{array}$ & $\begin{array}{c}-0.0022 \\
(0.0075)\end{array}$ \\
\hline Adj $R^{\wedge} 2$ & 0.1253 & 0.0979 & 0.0142 & 0.0112 & 0.0069 & 0.0440 \\
\hline Observations & 120505 & 120505 & 25909 & 25909 & 25909 & 25909 \\
\hline
\end{tabular}

Notes: $* * * / * * *$ statistically significant at $10 / 5 / 1 \%$ level. Standard errors are reported in parentheses. Regression also controls for 428 municipalities of residence age 19. Linear coefficients of parental attainment, earnings, and age are evaluated at sample median values (23 years of schooling, earnings of NOK 789384 , and ages 26 and 28). Earnings are the combined annual earnings of both parents between ages 11 and 15, inflated to 2015100000 NOKs. Mother and father's age are at child-birth, and marital status is at age 19 (omitted category is never married). 